\title{
Citra Tubuh Ideal Perempuan dalam Iklan Televisi
}

\author{
Lida Imelda Cholidah
}

UIN Sunan Gunung Djati Bandung

E-mail: limeldaz@gmail.com

\begin{abstract}
Abstrak
Advertising is one way to convey a message to the target audience are considered, and is used as a means of communication between producers and consumers. As communication tools, ads may expose the description of a product of each goals and objectives. Has an important role in an ad, either in print or electronic media. The use of women in advertising adds to the appeal to enjoy the advertising message. Because women are always displayed visually appealing, even though not necessarily the case. With the visualization of this it tends to cause a variety of different perception of the female image.Female ideal body imaging interpreted as a slim body, with no excess fat proportional portray the image of a beautiful woman. The image formed by the mass media often presents the symbols that represents the ideal female body as a symbol of beauty. Nevertheless imaging and acceptance and rejection of the ideal body will continue to rotate with the growth of industry, politics, advances in medicine, changes in the economy and the media.
\end{abstract}

\section{Kata kunci :}

Iklan, citra tubuh, perempuan

\section{A. Pendahuluan}

Memiliki bentuk tubuh yang ideal merupakan idaman setiap perempuan. Setiap perempuan pasti mendambakan tampil cantik pada setiap kesempatan. Apakah perempuan tersebut masih remaja, dewasa bahkan yang berusia senjapun ingin tampil cantik dan menarik dengan kodrat perempuan yang tidak dapat dipungkiri siapapun. Karena secara umum setiap individu tidak terkecuali laki-laki menyukai perempuan yang cantik, Walaupun persepsi mengenai cantik bisa dimaknai secara berbeda, artinya seorang laki-laki bisa mengatakan seorang perempuan cantik bukan hanya dilihat secara fisik, tapi juga bisa dilihat secara 
sosial atau sering kita dengar dengan kata inner beauty. Walaupun persepsi mengenai cantik bisa dimaknai secara berbeda, tetapi secara kasat mata seseorang dapat dikatakan cantik bila memiliki wajah dan tubuh yang enak dipandang dan proposional. Kecantikan telah menjadi permasalahan bagi perempuan selama berabad-abad. Hal ini dibuktikan dengan adanya perhatian khusus oleh perempuan terhadap penampilan fisik mereka terutama bentuk badan, serta bagaimana mereka menangani permasalahan berkaitan dengan kecantikan.

Melalui media massa khususnya televisi inilah, perempuan dijadikan sebagai komoditi yang merupakan wacana pemberian makna, penciptaan ilusi dan manipulasi sebagai cara untuk mendominasi selera masyarakat. Secara perlahan lahan media membentuk opini publik, keyakinan individu dan bahkan persepsi diri pribadi atau setiap orang, media mempunyai dampak yang sangat berarti pada proses sosialisasi masyarakat luas dan turut membentuk pemikiran dan ideologi.

Pencitraan kecantikan, dilakukan sedemikian rupa dan seringkali mendapatkan pembenaran dari kalangan perempuan sendiri. Umumnya, bagaimana perempuan menilai tubuhnya akan sangat berkaitan dengan bagaimana lingkungan sosial dan budaya diluar dirinya menilai tubuh perempuan. Artinya para perempuan akan selalu berusaha untuk menyesuaikan bentuk tubuh mereka dengan apa kata sosial dan budaya masyarakat mengenai konsep kecantikan itu sendiri. (Miranti Hidajadi dalam Jurnal Perempuan, 2000 : 10). Bentuk tubuh perempuan yang dianggap ideal bisa berubah-ubah, misalnya pada jaman Renaissance tubuh perempuan yang ideal adalah 'berisi'. Sebaliknya pada jaman Victoria bentuk tubuh ideal adalah langsing dengan lingkar pinggang yang kecil.

Praktek-praktek budaya massa yang ditimbulkan oleh adanya arus globalisasi, menyebabkan masyarakat yang tadinya mempunyai ciri khas budaya masing-masing (heterogen) menjadi disamakan dalam segala hal. Ketika masyarakat disamakan dalam setiap segi kehidupan terutama dalam rasa (taste) semisal seorang akan dikatakan cantik apabila bertubuh ramping ,kurus langsing semampai dengan ukuran yang kecil dan tanpa adanya kelebihan lemak sehingga perempuan yang bertubuh gemuk tidak termasuk dalam kategori cantik.

Setiap perempuan mendambakan tampil cantik. Kecantikan yang dimaksud adalah bentuk tubuh yang ideal yaitu bentuk tubuh yang langsing semampai. Penciptaan body image ideal dikarenakan 
perempuan telah melihat perempuan-perempuan bertubuh langsing yang berada di media massa, sehingga perempuan merealisasikan bahwa perempuan dipandang cantik bila mereka memiliki ukuran tubuh yang proporsional. Sehingga berbagai macam cara mereka lakukan untuk mendapatkan bentuk tubuh ideal. Baik dengan cara yang instan maupun dengan olahraga. Itu semua dilakukan perempuan untuk mendapatkan predikat cantik dari orang-orang disekelilingnya.

Industri kecantikan menawarkan berbagai produk yang dapat mempercantik perempuan sesuai dengan image yang diciptakan sehingga perempuan merasa tidak puas dengan tubuhnya. Disinilah iklan mendikte perempuan untuk memiliki tubuh ideal melalui produkproduk yang ditawarkannya. Naomi Wolf (Endah Muwarni dalam jurnal komunikasi ,2010:3) mengatakan bahwa perempuan rela menderita dengan melakukan diet dan menghabiskan banyak waktu (serta uang) untuk merawat tubuh agar tetap langsing, indah dan cantik. Berbagai produk yang berkaitan dengan bagaimana mempercantik wajah maupun tubuh ditawarkan oleh iklan.

\section{B. Kerangka Teori}

Citra adalah persepsi yang melekat pada sesuatu. Citra tidak bisa timbul begitu saja, melainkan perlu proses dalam pembentukannya. Menurut Betsy-Ann dan Jane Imber yang dikutip oleh Ritonga (2008: 24) mengutarakan bahwa citra adalah konsep khayalan yang diciptakan oleh iklan dan diproyeksikan oleh manusia, media yang mewujudkan emosi, persepsi, sikap dan pengelompokan orientasi intelektual menjadi satu kesatuan. Citra merupakan peta dunia seseorang. Ia merupakan gambaran terhadap suatu realitas dimana gambaran tersebut tidak harus sesuai dengan realitas. Lippman dalam Rakhmat (2002) menyebut citra sebagai gambaran di kepala (picture in our head).

Sementara itu Howard dalam Azhar (2008: 30) mendefinisikan citra sebagai semua kegiatan yang dilakukan maupun yang tidak dilakukan oleh lembaga, yang mempengaruhi persepsi masyarakat terhadap performance, product dan service lembaga.

Sementara Kasali (2000) mengatakan bahwa citra adalah kesan yang timbul karena pemahaman terhadap suatu kenyataan (realitas). Citra yang baik dimaksudkan agar organisasi dapat tetap hidup dan orang-orang didalamnya dapat terus mengembangkan kreativitas dan bahkan memberi manfaat yang lebih berarti bagi orang lain, melalui 
komunikasi terhadap produk ataupun program yang mampu menggambarkan realitas yang sebenarnya.

Menurut Frank Jefkins, citra diartikan sebagai kesan seseorang atau individu tentang sesuatu yang muncul sebagai hasil dari pengetahuan dan pengalamannya. Citra diperoleh berdasarkan pengetahuan dan pengertian seseorang tentang fakta-fakta atau kenyataan. Sedangkan menurut G. Sachs dalam Onong (1992:166) citra adalah pengetahuan mengenai kita dan sikap-sikap terhadap kita yang mempunyai kelompok-kelompok kepentingan yang berbeda. Citra adalah dunia sekeliling kita yang memandang kita.

Dari pengertian diatas, dapat dikatakan bahwa citra bersifat abstrak (intangible) dan tidak dapat diukur secara sistematis, tetapi wujudnya bisa dirasakan dari hasil penilaian baik atau buruk seperti penerimaan dan tanggapan, baik positif maupun negatif yang datang dari publik (khalayak sasaran) dan masyarakat luas.

Penggambaran secara visual mengenai tubuh ideal perempuan yang ditayangkan di dalam iklan televisi, menjadi informasi yang dijadikan sebagai pengetahuan bagi khalayak penonton sehingga muncul kesan bahwa tubuh ideal perempuan itu adalah seperti apa yang ditayangkan di dalam iklan tersebut, dan kesan inilah yang pada akhirnya akan melahirkan penilaian dan tanggapan dari khalayak sehingga terbentuklah citra mengenai tubuh ideal perempuan.

Ada beberapa defenisi yang dikemukakan para ahli mengenai citra tubuh atau body image. Cash (1994) menyatakan bahwa citra tubuh merupakan evaluasi dan pengalaman afektif seseorang terhadap karakteristik dirinya, bisa dikatakan bahwa investasi dalam penampilan merupakan bagian utama dari evaluasi diri seseorang. Cash dan Pruzinsky (1990) menyatakan bahwa citra tubuh merupakan gabungan dari gambaran, fantasi, dan pemaknaan individu tentang bagian dan fungsi tubuh yang dimiliki yang merupakan bagian dari komponen gambaran diri dan dasar representasi diri.

Sedangkan menurut Burn (1993:189) body image atau citra tubuh merupakan gambaran yang dimilik seseorang mengenai dirinya sendiri sebagai makhluk yang berfisik, sehingga citra tubuh sering dikaitkan dengan karakteristik-karakteristik fisik, termasuk didalamnya penampilan secara umum, ukuran tubuh dan berat tubuh, sosok dan bentuk tubuh serta detail-detail dari tubuh. 
Selain itu Centi (1997:36) mengartikan citra tubuh sebagai hal yang subjektif, menurut penglihatan diri sendiri. Keadaan dan penampilan diri pada gilirannya dipengaruhi oleh norma yang dijumpai atau yang dihadapi. Jersild dalam siawanti menambahkan bahwa tingkat body image atau citra tubuh ini digambarkan oleh seberapa jauh individu merasa puas terhadap bagian-bagian tubuhnya dan penampilan fisik secara keseluruhan. Perhatian terhadap penampilan fisik meliputi penilaian kehalusan wajah, kelangsingan tinggi tubuh dan berat tubuh.

Berdasarkan definisi di atas dapat disimpulkan bahwa citra tubuh merupakan gabungan dari gambaran mental, fantasi, sikap, pikiran, perasaan, pemaknaan, dan persepsi serta evaluasi seseorang mengenai tubuhnya yang meliputi bentuk, ukuran, berat, karakteristik, dan performansi tubuh. Individu dapat memiliki penilaian positif maupun snegatif terhadap citra tubuh diri.

Pemikiran bahwa tubuh yang kurus sebagai tubuh ideal banyak dipengaruhi oleh nilai dari kebudayaan Amerika. Nilai kebudayaan Amerika mengajarkan individualitas, kerja keras, kontrol diri, dan kesuksesan. Individu mendapat pesan bahwa dengan melakukan diet dan olahraga yang cukup, segala sesuatu bisa diatasi. Perempuan terkhususnya mendapat pesan bahwa dengan tubuh yang sempurna, pekerjaan dan kehidupan pribadinya akan sukses (Barnard, 1992). Standard kecantikan tubuh terus menerus berubah. Setiap zaman memiliki model citra tubuh tersendiri. Seiring dengan berubahnya gambaran tentang kecantikan tubuh tersebut, wanita mengharapka memiliki bentuk tubuh sesuai dengan gambaran tubuh yang ideal pada zaman tersebut.

Cohen (2001) memberikan gambaran tentang perubahan model citra tubuh yang dipengaruhi oleh kondisi ekonomi dan politik di Amerika, yaitu; Pada abad ke-18, tubuh ideal wanita yaitu tubuh yang berotot, besar, kuat, dan sangat subur sedangkan Pada abad ke-19, tubuh ideal wanita, yaitu tubuh yang lemah, lesu, dan pucat. Dan Pada abad ke-20, tubuh ideal wanita mengalami perubahan beberapa kali, yaitu mulai dari langsing, kuat dan berotot, keibuan, subur, serta sangat kurus dengan payudara yang besar. Kemudian abad ke-21, gambaran tubuh ideal wanita adalah tubuh yang kurus, seperti seorang model. Tubuh yang kurus menjadi standard ideal. Tidak jarang wanita melakukan sedot lemak untuk membuat bagian pinggul dan bokong 
terlihat lebih kurus. Sedangkan Komponen citra tubuh yang dikemukakan oleh Cash (2000) ada lima, yaitu ; pertama Appearance Evaluation (Evaluasi Penampilan), yaitu penilaian individu mengenai keseluruhan tubuh dan penampilan dirinya, apakah menarik atau tidak menarik, memuaskan atau tidak memuaskan. Kedua Appearance Orientation (Orientasi Penampilan), perhatian individu terhadap penampilan dirinya dan usaha yang dilakukan untuk memperbaiki dan meningkatkan penampilan dirinya. Ketiga Body Areas Satisfaction (Kepuasan terhadap Bagian Tubuh), yaitu kepuasan individu terhadap bagian tubuh secara spesifik, seperti wajah, rambut, payudara, tubuh bagian bawah (pinggul, pantat, kaki), tubuh bagian tengah (pinggang, perut), dan keseluruhan tubuh. Keempat Overweight Preocupation (Kecemasan Menjadi Gemuk), yaitu kecemasan menjadi gemuk, kewaspadaan individu terhadap berat badan, melakukan diet ketat, dan membatasi pola makan. Kelima Self-Clasified Weight (Persepsi terhadap Ukuran Tubuh), yaitu persepsi dan penilaian individu terhadap berat badannya, mulai dari kekurangan berat badan sampai kelebihan berat badan.

Berdasarkan pendapat Cash yang dikemukakan di atas, citra tubuh meliputi evaluasi dan orientasi individu terhadap penampilan tubuh, kepuasan pada bagian tubuh tertentu, serta persepsi dan penilaian terhadap berat badan.

\section{Citra Perempuan dan Media Massa}

Keindahan perempuan dan kekaguman lelaki terhadap perempuan adalah ceritra klasik dalam sejarah umat manusia. Dua hal itu pula yang menjadi dominan dalam inspirasi banyak pekerja seni dari masa kemasa. Namun ketika perempuan menjadi simbol dalam seniseni komersial, maka kekaguman-kekaguman terhadap perempuan itu menjadi sangat diskriminatif, tendensius, dan bahkan menjadi subordinasi dari simbol-simbol kekuatan laki-laki. Bahkan terkadang mengesankan perempuan menjadi simbol-simbol kelas sosial dan kehadirannya dalam kelas tersebut hanya karena kerelaan yang dibutuhkan laki-laki.

Eksploitasi perempuan dalam pencitraan media massa tidak saja karena kerelaan perempuan, namun juga karena kebutuhan kelas sosial itu sendiri, sehingga mau ataupun tidak kehadiran perempuan menjadi sebuah kebutuhan dalam kelas sosial tersebut (Bungin,2005:100). 
Selain itu, Bungin juga mengatakan pada kenyataannya, kehadiran perempuan dalam kelas sosial itu masih menjadi bagian dari refleksi realitas sosial masyarakatnya, bahwa perempuan selalu menjadi subordinasi kebudayaan laki-laki. Karenanya tetap saja perempuan di media massa adalah "perempuannya laki-laki"dalam realitas sosialnya.

Keindahan perempuan menempatkan perempuan dalam stereotip perempuan dan membawa mereka ke sifat-sifat disekitar keindahan itu, seperti perempuan harus tampil menawan, pandai mengurus rumah tangga, memasak, tampil prima untuk menyenangkan suami, dan pantas diajak keberbagai acara, cerdas, serta sumber pengetahuan dan moral keluarga. Stereotif ini menjadi ide dan citra sekaligus sumber protes terhadap iklan-iklan yang dianggap"melecehkan" citra itu. Namun menurut Bungin ada pandangan lain yang membantah, bahwa eksploitasi perempuan dalam media iklan, tidak sekedar karena stereotip perempuan, akan tetapi disebabkan umumnya pemirsa iklan adalah perempuan, dan barang-barang yang diiklankan juga adalah barang-barang disekitar perempuan atau yang berhubungan dengan perempuan. Perempuan sesungguhnya paling dekat dengan media massa, jadi tidak saja stereotip, namun segmen perempuan juga menjadikan alasan kuat mengeksploitasi perempuan dalam media massa.

Pada kesempatan lain, Ogilvy bapak periklanan modern . sebagaimana dikutip Bungin (2008: 103) mengatakan tugas utama iklan adalah menjual barang atau jasa, bukan menghibur. Ia juga mengatakan Horace Schwerin melaporkan bahwa tidak ada hubungan antara rasa suka kepada iklan-iklan dan termakan oleh iklan tersebut.

Kenyataannya kata-kata Schwerin ini tidak lagi menjadi acuan, karenanya ternyata menghibur sambil menjual di televisi menjadi lebih sama-sama menarik. Bagi para copywriter, iklan kendati mengetahui tidak ada hubungan antara iklan dengan keterpengaruhan pemirsa terhadap iklan tertentu, namun dorongan kapitalisme untuk menjadikan iklan sebagai medium pencitraan terhadap produk-produk kapitalisme lebih mempengaruhi jalan pikiran copywriter disaat mereka memulai pekerjaan mereka. Mereka meyakini bahwa iklan-iklan yang besar dengan pencitraan yang kuat, akan lebih besar kekuatannya mempengaruhi pemirsa, apalagi kalau pencitraan itu dilakukan melalui konstruksi realitas sosial, walaupun realitas sosial itu sifatnya semu. Hal 
ini menurut Bungin merupakan sebagian contoh dari upaya teknologi menciptakan "theater of mind" dalam kognisi masyarakat.

\section{Media Massa dan Simbolisasi}

Ketika kita merujuk pada kata media, maka yang dimaksud adalah industri media dan teknologi komunikasi yang terlibat dalam transmisi informasi dan hiburan antara pengirim dan penerima yang melintasi ruang dan waktu (Shaughnessy dan stadler,2005:3). Ada beberapa karakteristik media menurut Shaughnrssy dan Stadler,yaitu : pertama Media merupakan sistem komunikasi manusia artinya media merupakan salah satu sarana untuk melakukan komuniasi antar manusia. Kedua Media menggunakan teknologi industri untuk memproduksi pesan. Ketiga media umumnya bertujuan untuk menjangkau khalayak yang besar atau digunakan oleh banyak orang dan karenanya kadang-kadang disebut sebagai "media massa".

Kemudian Keempat media bertujuan untuk memungkinkan komunikasi melintasi jarak (dan / atau waktu) antara orang-orang, atau untuk memungkinkan komunikasi di mana pengirim tidak perlu hadir,komunikasi direkam dan ditransmisikan. Dengan menggunakan media khalayak dapat memperoleh informasi dengan mudah tanpa mereka harus terlibat langsung dalam proses komunikasi. Kelima media disebut 'media' karena mereka benar-benar di tengah, atau rantai menengah, dalam komunikasi (Media berarti "tengah" dalam bahasa Latin), mereka adalah mekanisme yang menghubungkan pengirim dan penerima pesan. Dan yang keenam pengembangan media telah dipengaruhi oleh kepentingan komersial yang mengakui bahwa media adalah industri berpotensi yang sangat menguntungkan.

Isi media pada dasarnya merupakan hasil pengkonstruksian sebuah realitas yang dibuat oleh pekerja media itu sendiri melalui symbol-simbol yang mereka buat sedemikian rupa sehingga pembaca, pendengar dan penonton bisa memaknai pesan yang mereka sampaikan melalui symbol-simbol tersebut sesuai dengan kerangka berfikir mereka. Sebuah makna tercipta karena ada hubungan yang kompleks antara symbol, objek, dan manusia yang melibatkan makna bersama (denotasi) dan makna pribadi (konotasi).

Dalam proses simbolisasi, simbol atau tanda menjadi hal yang sangat penting, karena simbol bagi manusia merupakan konseptualisasi tentang sesuatu hal. Simbol adalah gambar, bentuk atau benda yang 
mewakili suatu gagasan, benda ataupun jumlah sesuatu. Simbol yang paling umum adalah tulisan, yang merupakan simbol kata-kata dan suara atau disebut dengan bahasa yang didalamnya terdapat bahasa verbal dan nonverbal.

Bahasa adalah unsur utama dalam penciptaan makna. Ia merupakan instrumen pokok untuk menceritakan realitas. Bahasa adalah alat konseptualisasi dan alat narasi. Begitu pentingnya bahasa, maka tak ada berita, cerita, ataupun ilmu pengetahuan tanpa bahasa. Selanjutnya, penggunaan bahasa (simbol) tertentu menentukan format narasi (dan makna) tertentu. Sedangkan jika dicermati secara teliti, seluruh isi media entah media cetak ataupun elektronik menggunakan bahasa, baik bahasa verbal (kata-kata tertulis) maupun bahasa non verbal (gambar, foto, gerak-gerik, grafik, angka, dan label).

Proses simbolisasi juga terjadi pada iklan televisi, dimana iklan sarat dengan simbol-simbol yang mempresentasikan gagasan-gagasan atau ide si pembuat iklan. Proses simbolisasi terjadi ketika pemirsa televisi menginterpretasikan simbol-simbol yang dilihat kedalam benak mereka sesuai dengan latar belakang pengetahuannya dan sosio kultural yang dimilikinya, sehingga simbol-simbol tersebut membentuk sebuah makna.

Menururt Sugihastuti dalam bukunya wanita di mata wanita (1999: 28) bahwa citra perempuan berkaitan dengan citra diri, yang berlangsung secara intuitif atau refleksif, sehingga perempuan mempunyai andil yang besar dalam perwujudan sikap dan tingkah lakunya. Ada beberapa jenis citra perempuan yang berkaitan dengan penelitian ini, antara lain: citra pigura. Citra ini menggambarkan perempuan sebagai makhluk yang harus memikat. Untuk itu ia harus menonjolkan ciri biologis tertentu. Citra pilar. Jenis citra ini perempuan digambarkan sebagai pengurus utama keluarga. Citra Peraduan, citra ini menganggap perempuan sebagai objek pemuasaan laki-laki, khususnya pemuasan seksual, baik itu kecantikan secara alamiah maupun buatan (menggunakan kosmetik). Kemudian Citra Pinggan. Citra ini menjelaskan bahwa setinggi apapun perempuan dalam memperoleh gelar pendidikan dan sebesar apapun penghasilannya kewajibannya adalah di dapur. Dan yang terakhir adalah citra pergaulan. Dalam citra ini menurut subandi dan Suranto (1998,hal:333) perempuan digambarkan sebagai makhluk yang dipenuhi kekehawatiran tidak tampil memikat dan menawan, tidak presentable atau acceptable. 
Bentuk dan lekuk tubuh, aksentuasi bagian-bagian tertentu dengan menggunakan kosmetik dan aksesoris yang selaras sehingga seorang perempuan bisa anggun menawan, mengundang pesona dan ungguhungguh fisik perlu dijaga agar menarik dan tidak membawa implikasi rendah diri tertentu diarena pergaulan luas.

\section{E. Pencitraan Tubuh Ideal perempuan: Studi Iklan WRP Diet Center versi butterfly di televisi}

Masalah tubuh perempuan selalu menjadi perbincangan yang sangat menarik dikalangan perempuan itu sendiri. Pencitraan tubuh ideal perempuan yang terbentuk merupakan hasil konstruksi yang dilakukan media massa, salah satunya adalah oleh iklan. Iklan dengan komunikasi persuasifnya memperlihatkan simbol-simbol yang menggambarkan bagaimana citra tubuh ideal seorang perempuan. Pencitraan tersebut dibentuk sedemikian rupa sehingga pemirsa televise yang menonton iklan mengganggap bahwa apa yang diperlihatkan oleh iklan tersebut adalah sesuatu yang benar, sesuatu yang mencerminkan realitas yang sesungguhnya.

Dari sekian banyak iklan yang menampilkan sosok perempuan, yang paling menarik bagi penulis adalah iklan WRP Diet Center versi butterfly yang ditayangkan di televise. WRP Diet Center adalah salah satu divisi yang ada di PT Nutrifood Indonesia yang secara khusus bergerak dalam jasa konsultasi diet, kecantikan, dan perawatan tubuh wanita Asia modern. WRP merupakan salah satu nama produk diet yang dibuat oleh perusahaan Nutrifood. Produk ini menawarkan program penurunan berat badan dengan gizi lengkap dan kalori yang cukup.

Dari sisi konsep, pada dasarnya iklan ini dimaksudkan untuk menjadi tontonan yang semata-mata menjual. Seperti konsep-konsep iklan pada umumnya, tujuan utama iklan ini adalah untuk menjual produk WRP dan memperkenalkan WRP diet center sebagai tempat pelayanan diet bagi perempuan yang menginginkan bentuk tubuh yang ideal tanpa kehilangan nutrisi bagi tubuhnya. Iklan ini tidak ditujukan untuk memiliki unsur mendidik, karena tujuan dari sebuah iklan komersial adalah untuk menjual produk yang diiklankannya, bukan sebagai bahan edukasi. Iklan ini diharapkan mampu menyampaikan pesan mengenai konsep tubuh ideal bagi perempuan 
Secara umum Iklan WRP Diet Center versi butterfly ini menggambarkan seorang istri dan juga seorang ibu yang merasa dirinya bagaikan terlahir kembali setelah mengikuti program diet di WRP diet center serta mengkonsumsi produk dari WRP. Dalam iklan tersebut ceritra bersifat deskriptif, artinya sang bintang iklan menceritrakan ketika dirinya berpenampilan tidak menarik, dikarenakan gemuk. Dia merasa dirinya bagaikan si itik buruk rupa, sehingga dia malu ketika harus jalan bareng dengan suaminya dan malu ketika bertemu dengan teman-temannya. Setelah mengikuti program diet di WRP diet center dan mengkonsumsi produk dari WRP perempuan tersebut merasa dirinya bagaikan terlahir kembali, dan si itik buruk rupapun berubah menjadi kupu-kupu cantik.

Digambarkan pula kecenderungan warna yang ada dalam iklan tersebut adalah warna putih dan merah yang mendominasi, juga ada warna hitam yang ditayangkan pada saat keadaan perempuan tersebut gemuk. Menuerut Michael Danesi (2010:49) setiap warna mempunyai arti yang melambangkan sesuatu mempunyai warna seperti itu. Warna putih pada pakaian yang dikenakan oleh perempuan yang ada didalam iklan tersebut serta warna yang mendominasi background iklan tersebut menggambarkan kebaikan, kesopanan dan kesucian. Selain itu warna merah yang mendominasi pakaian sang bintang iklan dapat diartikan hasrat, seksualitas, kesuburan, berbuah, kemarahan dan sensualitas serta warna hitam yang menggambarkan hal-hal yang sifatnya negative, seperti jahat, ketidakmurnian, keadaan bersalah, kejahatan, dosa, ketidaktulusan, keadaan tidak bermoral. Warna hitam ini terlihat pada visualisasi ketika perempuan itu berbadan gemuk.

Namun sebagai catatan untuk diingat, sifat dasar teks media, termasuk iklan didalamya adalah polisemik, yang memungkinkan timbulnya multiple interpretations. Interpretasi tersebut tergantung pada pola pikir dan kondisi social penerima teks, bukan dari struktur penerima teks itu sendiri. Oleh karenanya interpretasi penerima teks bisa saja berbeda dengan apa yang telah dikonsepkan dalam teks media tersebut. Begitu juga dengan iklan "WRP Diet Center versi butterfly ini, apa yang dikonsepkan oleh pencipta iklan dapat diinterpretasi secara multiple oleh audiens yang berbeda-beda.

Iklan WRP Diet Center versi butterfly yang ditayangkan di televise berperan sebagai stimulus bagi pemirsa televise yang menontonnya sehingga menimbulkan pengetahuan mengenai apa itu produk WRP, 
bagaimana produk tersebut bisa membentuk tubuh ideal perempuan dan kenapa perempuan harus memiliki tubuh ideal yang secara visualisasi merupakan tubuh yang langsing, proposional dan tanpa kelebihan lemak. Efek kognitif dari komunikasi sangat mempengaruhi proses pembentukan sebuah citra, karena citra terbentuk berdasarkan pengetahuan dan informasi-informasi yang diterima, dalam hal ini adalah informasi mengenai bentuk tubuh ideal perempuan yang divisualisasikan dalam iklan WRP Diet Center yang kemudian diolah dalam benak pemirsa seiring interaksinya dengan dunia sosio-kultural nya sehingga terjadi proses eksternalisasi, objektivasi dan internalisasi yang menghasilkan pencitraan mengenai bentuk tubuh ideal perempuan, yang divisualisasikan dalam iklan WRP Diet Center versi butterfly sehingga citra yang dihasilkan dari iklan tersebut adalah bahwa bentuk tubuh ideal perempuan itu adalah tubuh yang langsing, proposional dan tanpa kelebihan lemak. Walaupun demikian, pencitraan dan penerimaan serta penolakan tubuh ideal akan terus berputar seiring pertumbuhan industry, politik, kemajuan bidang kedokteran, perubahan ekonomi dan media massa.

\section{F. Penutup}

Iklan adalah suatu bentuk kekuatan komunikasi yang luar biasa, dan merupakan alat pemasaran yang vital. Membantu untuk menjual barang, jasa, pelayanan, citra, dan ide, melalui saluran informasi dan persuasi (Wright dkk, 1978:.5). Pelaku iklan memberikan informasi kepada seseorang yang mencari informasi tersebut. Iklan merupakan cara yang paling efektif untuk mencapai orang-orang dengan informasi produk. Menghubungkan komunikasi antara seseorang dengan sesuatu yang ingin dijualnya dan seseorang yang membutuhkan sesuatu. Persuasi adalah suatu tujuan aktif untuk mempengaruhi orang-orang untuk bertindak atau percaya dengan seruan yang terang-terangan untuk alasan atau emosi. Untuk dapat menjalankan fungsi pemasaran, maka apa yang harus dilakukan dalam kegiatan periklanan tentu saja harus lebih dari sekedar memberikan informasi kepada khalayak. Periklanan harus mampu membujuk khalayak ramai agar berperilaku sedemikian rupa sesuai dengan strategi pemasaran perusahaan untuk mencetak penjualan dan keuntungan. Singkatnya "periklanan harus dapat mempengaruhi pemilihan dan keputusan pembeli. 
Menurut Idi subandy Ibrahim dalam bukunya "kritik Budaya Komunikasi", saat ini perempuan dibombardir oleh citra-citra "perempuan ideal" yang dikonstruksi melalui dan oleh media. Citra ideal perempuan agar selalu tampil memesona menjadi tema sentral iklan media popular.Menurutnya walaupun citra perempuan memiliki fungsi sebagai cermin, sayangnya cermin tersebut tidak menggambarkan kealamian dan keautentikan dunia wanita, karena tak jarang ia malah mempromosikan kehidupan yang tidak realistis, alias impian atau ilusi belaka. Hal inilah yang membuat wanita cemas dengan ketidakidealan citranya saat dibandingkan dengan citra-citra iklan yang ada.

\section{DAFTAR PUSTAKA}

Belch/belch. 2009. Advertising and Promotion, An Integrated Communications Perspective. New York : McGraw-Hill International Edition

Burns, R.B.1993. Konsep Diri: Teori, Pengukuran, Perkembangan dan Perilaku. Alih bahasa :Eddy.Jakarta: Arcan

Bungin Burhan. 2008. Sosiologi Komunikasi, Teori, Paradigma, dan diskursus teknologi Komunikasi di Masyarakat. Jakarta Prenada media Group

2005. Pornomedia, Sosiologi Media, Konstruksi sosial Teknologi telematika, \& Perayaan Seks di Media Massa : Jakarta :Prenada Media

2001, Imaji Media Massa, Yogyakarta, Jendela

Centi, P.J. 1997. Mengapa Rendah Diri. Alih bahasa: A.M. Hardjana. Yogyakarta: Kanisius

Curran, James\&Mitchel Gurevitch.1991.Mass Media \& Society. USA : Edward arnold

Danesi Marcel. 2010. Pengantar memahami Semiotika Media. Yogyakarta :Jalasutra

Fiske, John. 2012. Cultural and communication studies : Sebuah Pengantar Paling Komprehensif. Yogyakarta: Jalasutra

2012. Introduction to Communication Studies. Londdon : Routledge Mulyana deddy \& Ibrahim Subandy Idi. 1997. Bercinta dengan Televisi. Bandung : Remaja Rosda Karya 
Idi subandi Ibrahim dan Hanif Suranto, 1998. wanita dan Media, Bandung, PT Remaja RosdaKarya

Jefkins Frank. 1996. Public Relations, edisi keempat. Jakarta : Erlangga

Jefkins Frank. 1997. Periklanan, edisi ketiga : Jakarta : Erlangga

Kasali Rhenald. 1992. Manajemen Periklanan :Konsep dan Aplikasinya di Indonesia. jakarta : PAU UI \& Grafiti

Kasali Rhenal. 2000 . Manajemen Publik Relations: Konsep dan aplikasinya di Indonesia. Pustaka Utama Grafiti, Jakarta

Littlejohn, Stephen W \& Foss Karen A. 2009. Theories of Human Communication Penerbit Salemba Humanika

Littlejohn, Stephen W, 2002 Theories of Human Communication, Edisi 7, Belmont, California: Wadsworth Publishing Company

Mirza Ronda dalam Penelitian Analisa semiotik, Citra Perempuan dalam Televisi, Jurnal Ilmu Komunikasi Usahid, vol 2,no 10 september 2011

Rakhmat Jalaludin, 2008 . Psikologi Komunikasi, Bandung : Rosda Karya

Shoemaker, Pamela J, \& Stephen D. Reese. 1996. Mediating The Message 2nd. USA : Longman Publisher

Shimp Terence A.2000. Periklanan Promosi, Aspek Tambahan komunikasi pemasaran Terpadu, edisi kelima. Terjemah. Jakarta: Erlangga

Soleh Soemirat dan Elvinaro Ardianto. 2010. Dasar-Dasar Public Relations. Bandung : Rosda

Shaughnessy Michael 0', stadler Jane. 2005 Media and Society an introduction third edition Oxford. University Press. 